\title{
DEVELOPMENT OF TUNA FISHERIES MANAGEMENT STRATEGIES FOR THE SOUTHERN COAST OF JAVA: AN APPLICATION OF INTERPRETATIVE STRUCTURAL MODELING
}

\author{
Tri Wiji Nurani ${ }^{1)}$, John Haluan ${ }^{1)}$, Ernani Lubis ${ }^{1)}$, Sudirman Saad ${ }^{2)}$, and Ririn Irnawati ${ }^{3)}$ \\ 1) Lecturer in Faculty of Fisheries and Marine Science, Bogor Agricultural University, Bogor \\ 2) Secretary of the Directorate General of Coastal and Small Island, Ministry of Marine Affairs and Fisheries \\ 3) Graduate Student on System and Modeling of the Marine Fisheries, Bogor Agricultural University, Bogor \\ Received November 30-2009; Received in revised form August 12-2010; Accepted December 2-2010
}

\begin{abstract}
Territorial waters of South Java is part of fisheries management zone of Indian Ocean Fisheries, has a potential tuna fish resources. The purpose of this research was to formulate strategy for the efficacy of model implementation of tuna fisheries development in South Coast of Java. Interpretative structural modeling technique was used the study. The method was considered a technique of strategic planning of which describes comprehensively condition of the system. Result showed that there were seven element of system require for succeeding implementation of model. The seven element of system and their key element are affected society sector, tuna entrepreneur, required factor, the availability of tuna resources and the availability of data and information, the main constraint of program development, high gasoline price, limited of financial capital and low priority of development fund, the main purpose of program: exploiting optimization of tuna resources; the indicator of the efficacy program: increasing the earn of tuna fishery and improvement of labor absorption; the activity needed to execute the program: making plan work activity; and institution in concerned for the efficacy program: Ministry of Marine Affairs and Fisheries.
\end{abstract}

KEYWORDS: $\quad$ fisheries management, interpretative structural modeling, tuna, South Coast of Java

\section{INTRODUCTION}

South Java territorial waters is part of fisheries management zone of Indian Ocean with potential tuna resources potency, especially bigeye tuna (Thunnus obesus) and yellowfin tuna (Thunnus albacares). The potency of tuna resources in this territorial is not yet determined. The Indian Ocean Tuna Commission Working Party on Tropical Tuna (2009) described that catch rate big eye tuna in Indian Ocean continuously decreased from around 9,0 in 1960 to 3,2 in 2002 when it has increased to about 4,4 ; about the same level as that in the late 1990s, decreased to 2,3 in 2003 and increased to 3,0 in 2004. Meanwhile catch per unit of effort yellowfin tuna continuously decreased from around 28,7 in 1960 to 10,5 in 1972, and was kept at approximately the same level until 1988, thereafter it declined to about 4,5 in 1994 and has remained at his low level with fluctuations between 3,3 and 4,6 until 2006, was much lower 3,0 in 2007 (http://www. lotc.org/files/proceedings/2009/wptt/IOTC). It seems that tuna fisheries in Indian Ocean is on fully exploited. Because of that, development of tuna fisheries in South Coast of Java should be more emphasize to management of tuna fisheries according to sustainability.

Nurani et al. (2008) developed a SIMPENA model of tuna fisheries in South Coast of Java, which focused on development of tuna fisheries in small scale with gross tonnage of fishing vessel less than 150 GT. Development of tuna fisheries in south coast of Java will be succeeded, if the existing subsystem which business, port, and instituton subsystem could be function well (Figure 1). The model was resulted through research by system approach method. The model recommended several thing, that are development conducted by means of build industrial scale of tuna fisheries business; support by fishing port with international standard; applying good handling practices and standard sanitation operational procedure on fishing vessel and fishing port; recommended as the basis of tuna fisheries are Cilacap and Pelabuhan Ratu fishing port, with 170 units of long line fishing vessel; and integrated management institution should be formed to integrate manage tuna resources, which accommodate the need between province and sub province, and also between stakeholder. 


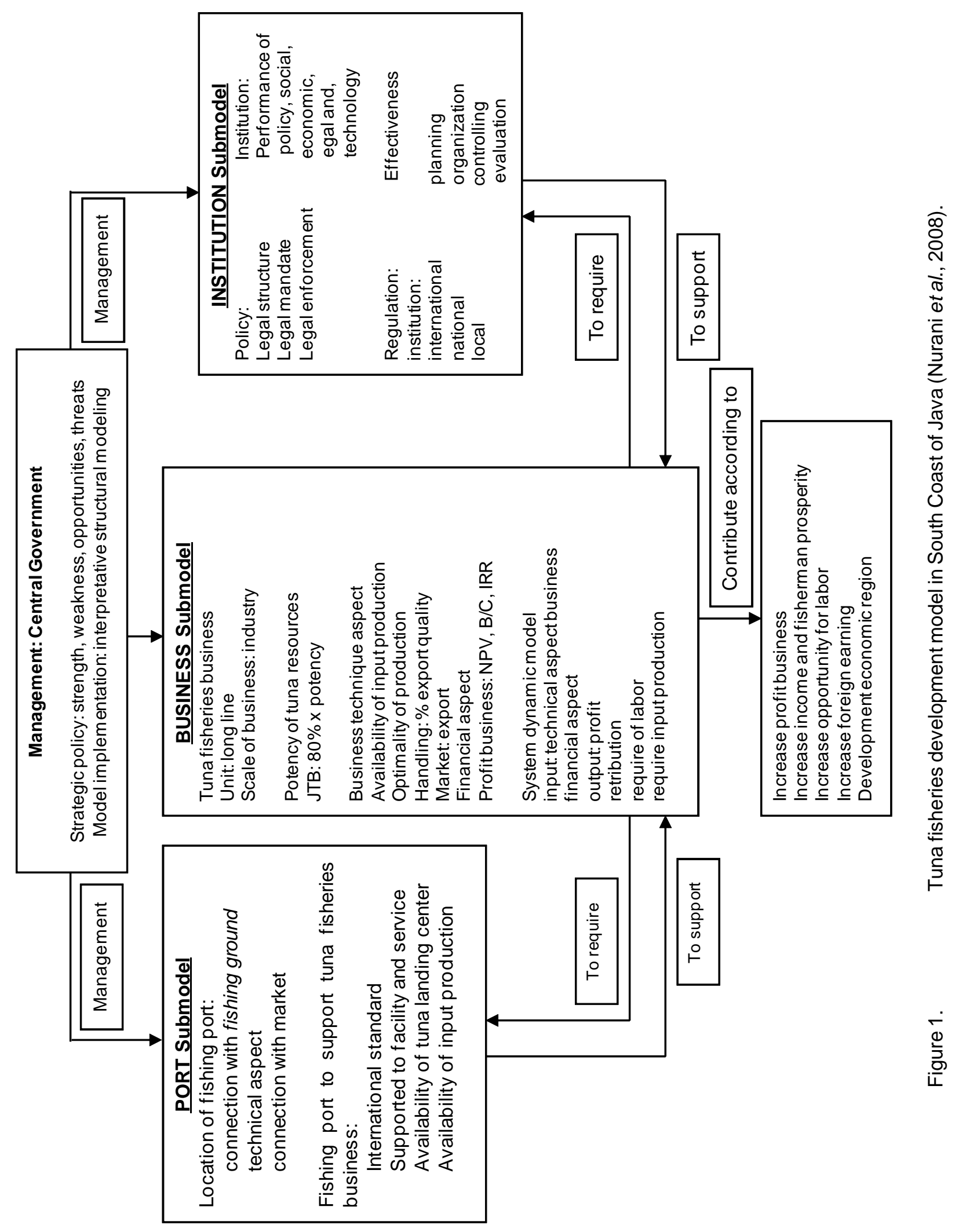


As previously mentioned, Simpena model was designed for development of tuna fisheries in South Java territorial water. The benefit of model will be realized in the real system. Many factors including system will affect to the efficacy of applying model. Suitable strategy is required to formulate by studying comprehensive factor that will effect to the efficacy of applying model. One of the techniques to describe the complex things of system is interpretative structural modeling technique.

Interpretative structural modeling is a descriptive effective modeling for strategic long range planning. Strategic planning includes system totality which can't be analyzed partly, but should comprehensively. Interpretative structural modeling technique analyzed the element of system, and describe in graph form direct relation between element and hierarchy. Data and information which available in strategic planning, usually predominated by data and information which qualitative and normative characters (Eriyatno, 2003; Marimin, 2004).

Interpretative structural modeling technique was a group learning process where the structural models are result for describing the complex things of system. Model is designed through pattern which is carefully designed use graph and sentence. The method gives perfect environment to enrich and enlarge description on complex system construction. (Eriyatno, 2003; Marimin, 2004; Gorvett \& Liu, 2007).

Interpretative structural modeling technique has used in many study. Some studied are the study of crumb rubber repaired agro industry (Utomo et al., 2008), the decision making study of forest ecosystem management (Liu et al., 2009), the study of vendor selection (Mandal \& Deshmukh, 1994), group decision making (Balanos et al., 2005), and study of food standard accomplishment condition (Sagheer et al., 2009).

The objective of the research is to formulate suitable strategy in applying development model of tuna fisheries in South Coast of Java using interpretative structural modeling technique.

\section{MATERIALS AND METHODS}

This paper was a part of research result for development of fisheries in South Java territorial waters. The research of fisheries activity was conducted during July 2005 until July 2007 in Sukabumi, Garut, Cilacap, Kebumen, Gunung Kidul, Pacitan, Trenggalek, and Malang sub province.

\section{Data Collection}

Implementation strategy of applying this model was conducted using the focus group discussion, with various type of stakeholders. The stakeholders include tuna entrepreneur, fishermen, fishing port organizer, processing industry entrepreneur, exporter, consumers, fisheries agency, local government, village cooperation organizer, elite figure, self supporting society institute, and expert in fisheries field.

\section{Data Analysis}

Interpretative structural modeling technique was divided into two part composing of hierarchy and sub element classification. First phase was generating tool, passing gathering information from stakeholders. Second phase was choosing relevant relationship, so the elements can be formulation (Eriyatno, 2003).

Analysis step with interpretative structural modeling technique were:

1. System element identification.

2. Develop contextual relation among element which adapted with the model purpose.

3. Making structural self interaction matrix. Matrix made base to responder perception through focus group discussion. Four symbols for representing existing relation type among two element of the considered system are:

$V$ : relation from $E_{i}$ to $E_{i,}$, not on the contrary.

$A$ : relation from $\mathrm{Ej}$ to $\mathrm{Ei}$, not on the contrary.

$X$ : relation among $E_{i}$ and $E_{i j}$ (on the contrary).

$\mathrm{O}$ : indicating that $\mathrm{E}_{\mathrm{i}}$ and $\mathrm{E}_{\mathrm{i}}$ is not interconnected.

4. Making reach ability matrix: a reach ability matrix which is prepared later changed structural self interaction matrix symbols to a binary matrix. Converting rule applying:

a. If relation $\mathrm{E}_{\mathrm{i}}$ to $\mathrm{E}_{\mathrm{i}}=\mathrm{V}$ in structural self interaction matrix, so element $E_{i j}=1$ and $E_{i j}=0$ in reach ability matrix.

b. If relation $E_{i}$ to $E_{i}=A$ in structural self interaction matrix, so element $E_{i j}=0$ and $E_{j i}=1$ in reach ability matrix.

c. If relation $E_{i}$ to $E_{i}=O$ in structural self interaction matrix, so element $E_{i j}=0$ and $E_{i j}=0$ in reach ability matrix.

Early reach ability matrix modified to show all direct and indirect reach ability, that is if $\mathrm{E}_{\mathrm{ij}}=1$ and $E_{i k}=1$, so $E_{i k}=1$.

5. Participation level conducted to classify element in different level of interpretative structural modeling technique. For this purpose, two tools associated with every element Ei of the system reach ability set $\left(R_{i}\right)$, is a set from all element which is reached from $E_{i}$ element, and antecedent set $\left(A_{i}\right)$, is a set 
from all element where $E_{i}$ element can be reached. At first iteration of all element, where $R_{i}=R_{i} \cap A_{i}$, are first level elements. At the next iteration, elements identified like level elements in eliminated previous iteration, and new elements is selected for next levels by the same rule. Then, all system elements grouped to different levels.

6. Making canonical matrix: elements grouping to the same level develop this matrix. Resultant matrix has most of higher triangular elements is 0 and lowest 1 . This matrix then used to prepare digraph.

7. Making digraph: a concept coming from directional graph, a graph from elements which direct relation, and hierarchy level. Early digraph is prepared in canonical matrix basis. That early digraph then is cutting by removing all transitive components for making final graph.

8. The evocation of interpretative structural modeling: interpretative structural modeling awakened by removing all elements by describing actual element. For that, interpretative structural modeling gives clearly depicting the system elements and relation path.

The outputs of interpretative structural modeling technique are each sub element ranking and sub element plot in four sectors with their quadrants. The sectors are:

1. Sector I: weak driver weak dependent variables. Sub element which enter this sector commonly is not relation with the system or few relation. Sub element in sector I, if driver power value $\leq 0,5 \mathrm{X}$ and dependence value if $\leq 0,05 X$; where $X$ was the number of sub element.

2. Sector II: weak driver strongly dependent variables. Commonly the sub element which entered this sector is un free sub element. Sub element in sector II, if driver power value $\leq 0,5 \mathrm{X}$ and dependence value $\geq 0,5 \mathrm{X}$.

3. Sector III: strong driver strongly dependent variables. Sub element which enter in this sector should carefully study, because of unstable relation between sub element. Every action at sub element will impact to other sub element and feed back effect can enlarge the impact. Sub element in sector III, if driver power value $>0,5 \mathrm{X}$ and dependence value $>0,5 X$.

4. Sector IV: strong driver weak dependent variables (independent). Sub element which enter this sector was a remains part of system and called independent variable. Sub element in sector IV, if driver power value $>0,5 \mathrm{X}$ and dependence value $\leq 0,5 X$.

\section{RESULTS AND DISCUSSIONS}

From the application of the model for tuna fisheries in south coast of Java, it has been realized that there are seven system elements requiring consideration. The efficacy of development program require priority and emphasize at sub element becoming key sub elements. Key sub element will drive other sub elements in the system, for succeeding program.

In the driver power dependence matrix, represent sub element which strong depended to other sub element in the system. In this condition sub element is labile, or easy change by change influence from other sub element. Sub element of system also have drive power that strong or weak to drive the efficacy of program (Eriyatno, 2003; Marimin, 2004).

Development program of tuna fisheries in south coast of Java to be success, with priority for sub element in sector III, are sub element which strongly depended with other sub element in the system and strongly driver to system efficacy. Attention also required to sub element in sector IV, with sub element consideration in this sector was independent variable which effect to other sub element, and also strongly drive for succeeding development program.

The result of gathering information from stakeholder, obtained seven elements which is need considered in applying model of tuna fisheries development in south coast of Java. The seven element are affected society sector; required factor; main constraint; main purpose; indicator of the efficacy; require activity; and institute concerned for success the program.

\section{Affected Society Sector}

The structural model diagram of affected society sector in developing tuna fisheries in South Coast of Java was presented in Figure 2a. Tuna fisheries business is key sub element to drive sub element in the level above for succeeding program. It can be comprehend because in tuna fisheries, capital released for operational cost is very high. Disability of entrepreneur to conduct operation trip, like increasing gasoline, will resist other sub elements, for example unemployment of ship worker, lacking raw material supply for tuna processing industry, lacking tuna product for exporter and others.

Sub element distributed in sector II, III, and sector IV in driver power dependence matrix. Tuna entrepreneur and fisherman reside in sector IV. Bait capture fisherman, provision seller, tuna processing industry, merchant, and exporter are in sector III. Sub 
element in this sector have high depended to another sub element. The lack of attention to this sub element will resist the successful program of tuna fisheries development (Figure 2b)

\section{Required Factor for Succeeding Program}

Structural model diagram of required factor for succeeding program on development of tuna fisheries express that the availability of tuna resources and the availability of data and information were key element. Sub elements in next level are the availability of human resources, the availability of technology, and also law enforcement (Figure 3). Information about stock availability is basic for sustainable resources utilization effort. Several sustainable efforts require for management the stock availability of tuna fisheries, for better management.

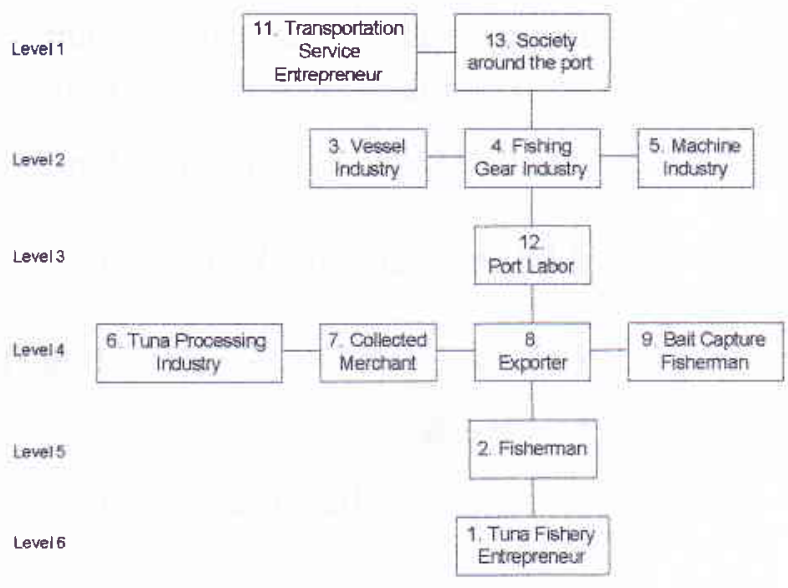

Figure 2a. Structural model of affected society sector.

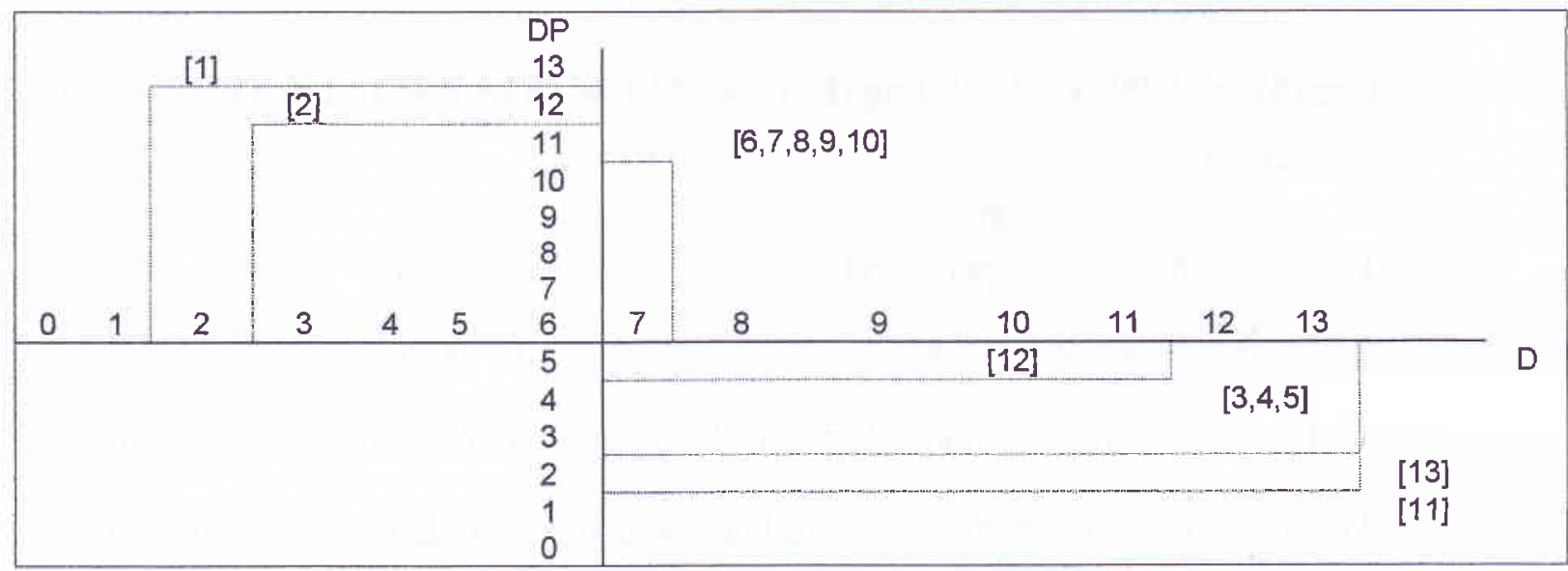

Figure 2b. Driver power dependence matrix of affected society sector.

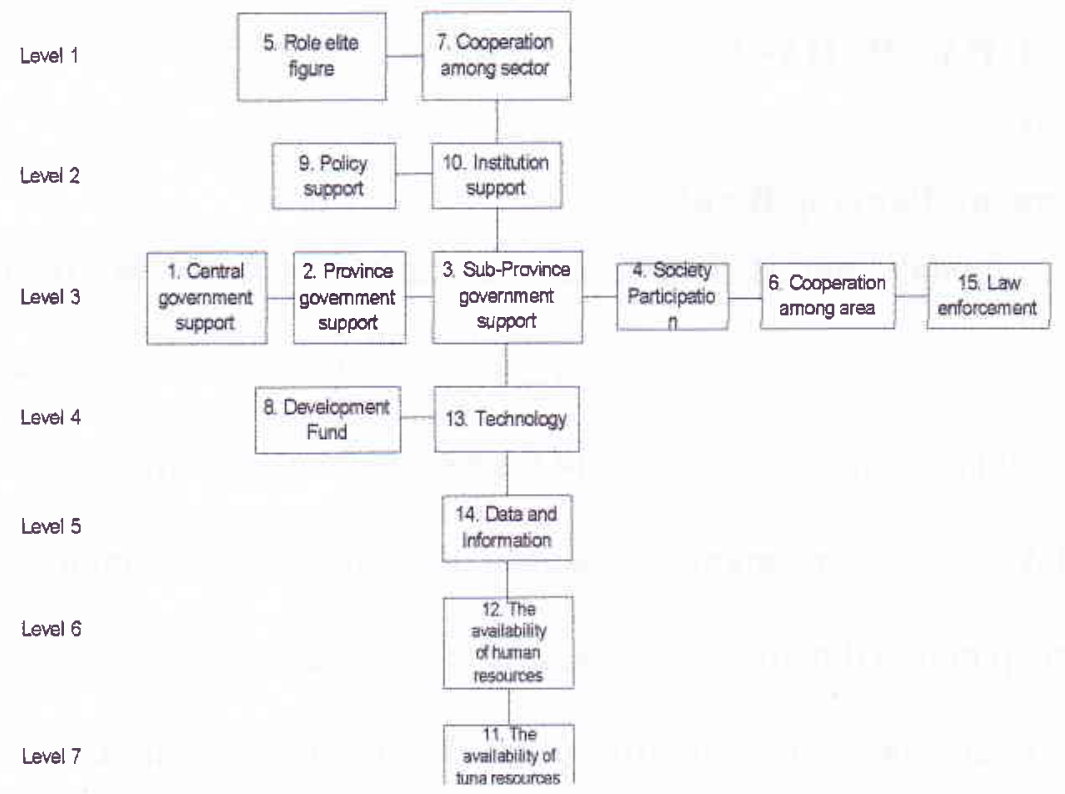

Figure 3. Structural model of required factor for succeeding program. 
Result of sub element plot at driver power dependence matrix, distribution sub element most in sector III. This Matter shows most sub element from required factor for the efficacy of program have strongly depended with other sub element in system. The availability of tuna resources and the availability of human resources were in sector IV.

\section{Main Constraint of Development Program}

Structural diagram model for the element of main constraint of program development, high gasoline price, development fund priority which still lower and the ability of limited capital from businessmen were key element from the main constraint of program (Figure 4). The main constraints have to handle, before overcoming the other problems. Not supporting gasoline price in fisheries effort is important factor became constraint for fisheries development. At industrial fisheries like tuna fisheries, gasoline cost reach 30\% from overall operational cost requirement. Existence of increasing gasoline at October 2005, have increased gasoline cost become $50 \%$ from overall effort requirement. Increasing gasoline cost caused entrepreneur face heavily problem and difficult to conduct operation (Nalendra, 2007).

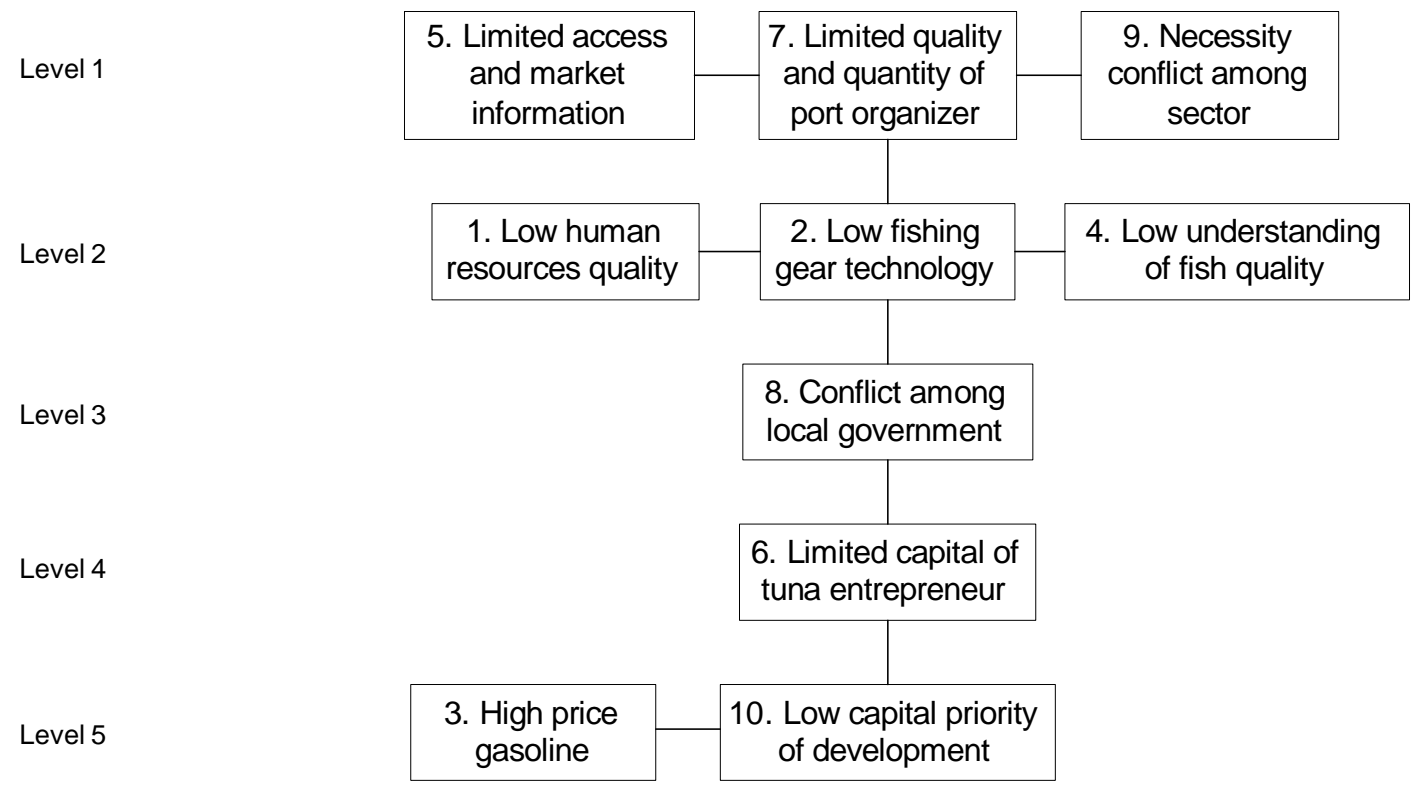

Figure 4. Structural model of the main constraint of development program.

Result of element plot in driver power dependence matrix, sub element most distributed at sector III, except high gasoline price, the ability of limited capital from entrepreneur and low development fund priority which reside in sector IV. This matter indicate that most sub element have depended and high drive to system. Unhandled one of the sub element will effect to unhandled problems of other system sub element, and also will give feed back to unsuccessful of applying model.

\section{The Main Purpose of Program}

Sub element of the main target of program structured in four levels. Optimization of fish resources utilization, increasing income and fisherman prosperity and also increasing of labor absorption were key element from the main purpose of program (Figure 5). Reaching the objective from that sub elements, will drive to reach other purposes of development tuna fisheries program in South Coast of Java. This match with Dahuri Statement (2003) that policy and related program with optimization of fish resources availability with utilization level in every area is important to guarantee profitable and sustainable fishery effort.

Optimization of fish resources was in sector IV, expressing this sub element can influence other sub elements and also have a big drive for succeeding the system. The increasing of profit effort, increasing income and fisherman prosperity, increasing job opportunity, increasing port functionality, increasing port accessibility, increasing local income, and economic of area reside in sector III. This expresses, each purpose of program is strongly depended. Unfulfilled one of the purpose at this sector, will effect to the unfulfilled of the other target of the program sub,elements. 


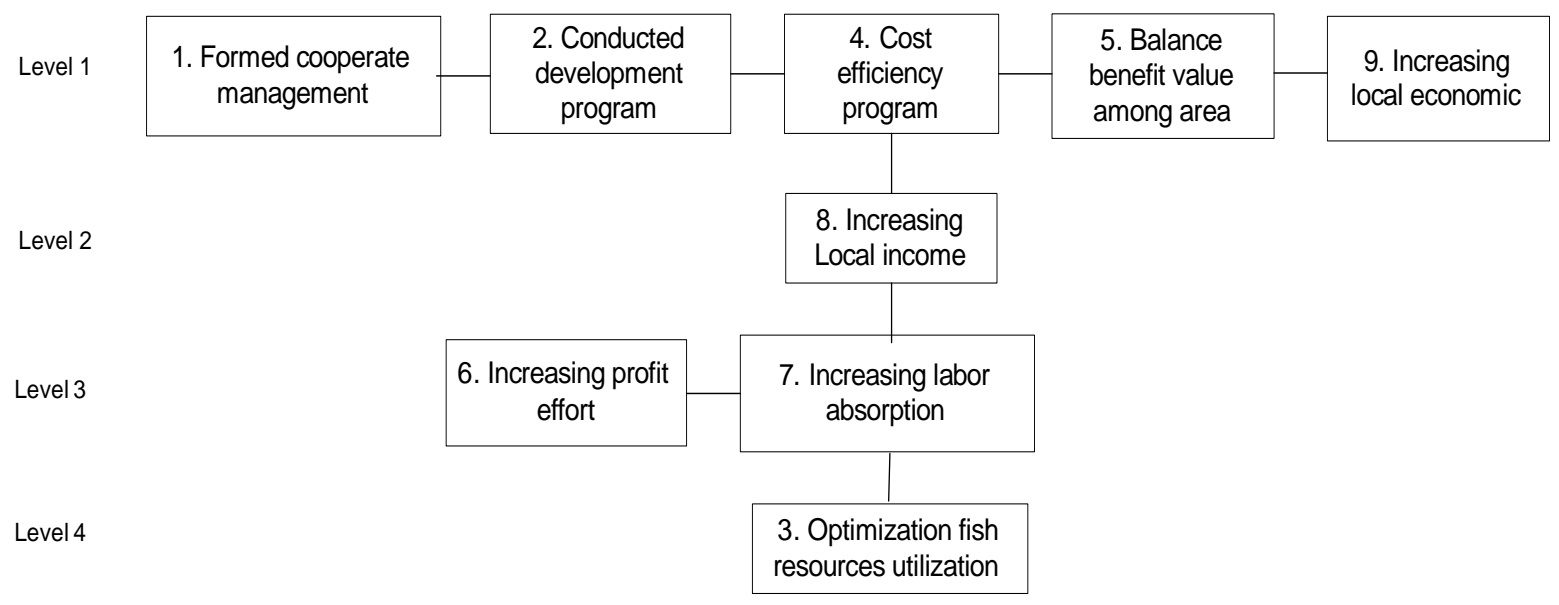

Figure 6. Structural model of indicator for the efficacy of program.

\section{The Indicator for the Efficacy of Program}

The indicator for the efficacy of program placed optimization of fish resources utilization, increasing income of fishery effort, and also increasing labor absorption were key element (Figure 6). The reaching of sub element from indicator of program efficacy will push to reach the other measuring rod sub element.

Driver power dependence matrix from the measuring rod element efficacy of program plot most of sub element into sector III, except optimization of fish resources utilization, increasing income of fishery effort, and also increasing labor absorption in sector IV. This express that most of sub element from indicator of program efficacy depended and high drive as the measuring rod efficacy of development tuna fishery.

\section{Required Activity for Successful Program}

Activity of making work plan for managing tuna resources was key element, which must there before other activity which side in the level above (Figure 7). Next activity is making law regulation to careful manage tuna resources. Education and human training, technological development, the availability of infrastructures, supporting condition, and development of market access was one level above.

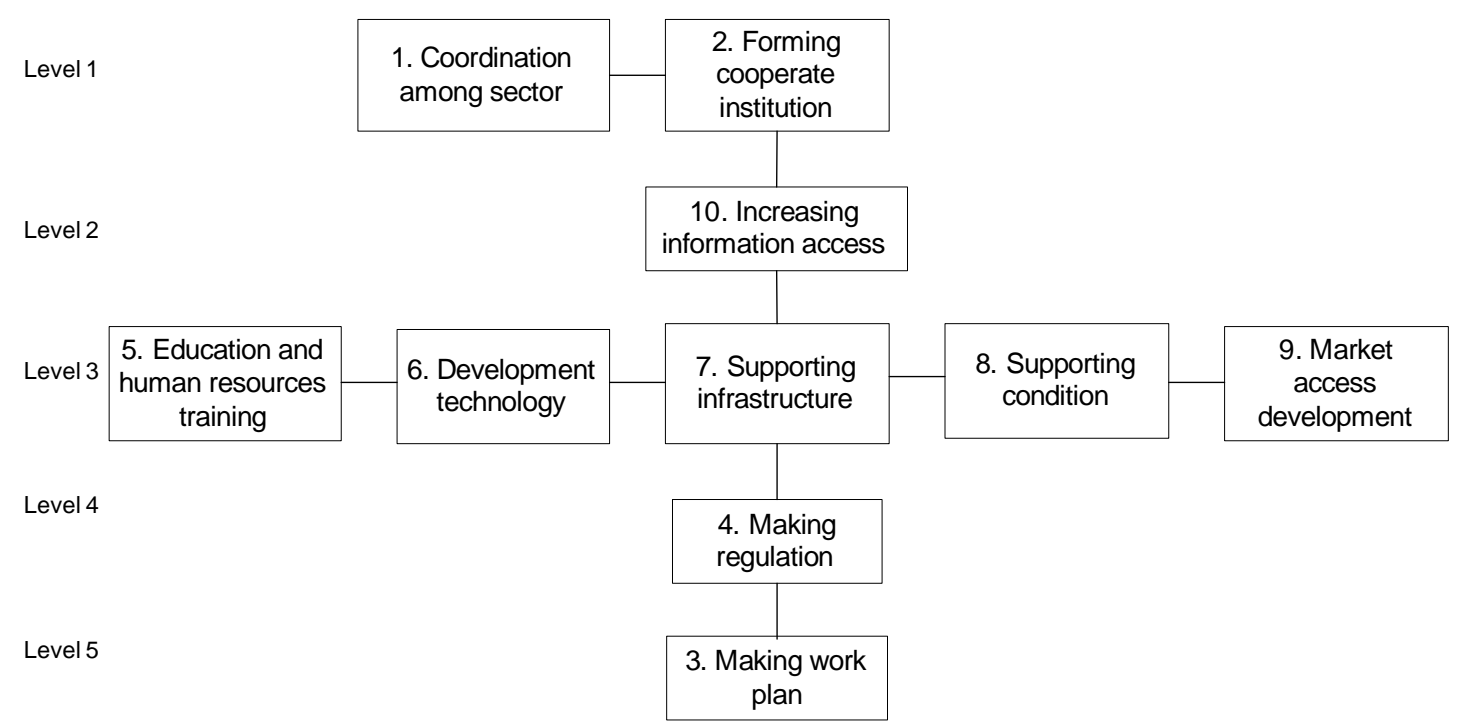

Figure 7. Structural model of require activity for successful program. 
Education and human training, development of technology, the availability of infrastructure, supporting condition, development of market access, and increasing information access were in sector III. Making work plan for managing fish resources and making regulation were in sector IV. That sub element can influence other sub elements and also have strong drive to successful of development program. Labor has important role for succeeding tuna catch operation. Labor at long line vessel is expected have international seaman license according to SCTW standard 1978 (standard of training certification watch keeping for seafarers).

\section{Institution Concerned for the Efficacy of Program}

The Ministry of Marine Affairs and Fishery was key sub element from concerned institution element at development tuna fisheries program. Other Institution which has important involvement are the Province Fisheries Agency, the sub Province Fisheries Agency, marine transportation Agency, and fishing port organizer (Figure 8).

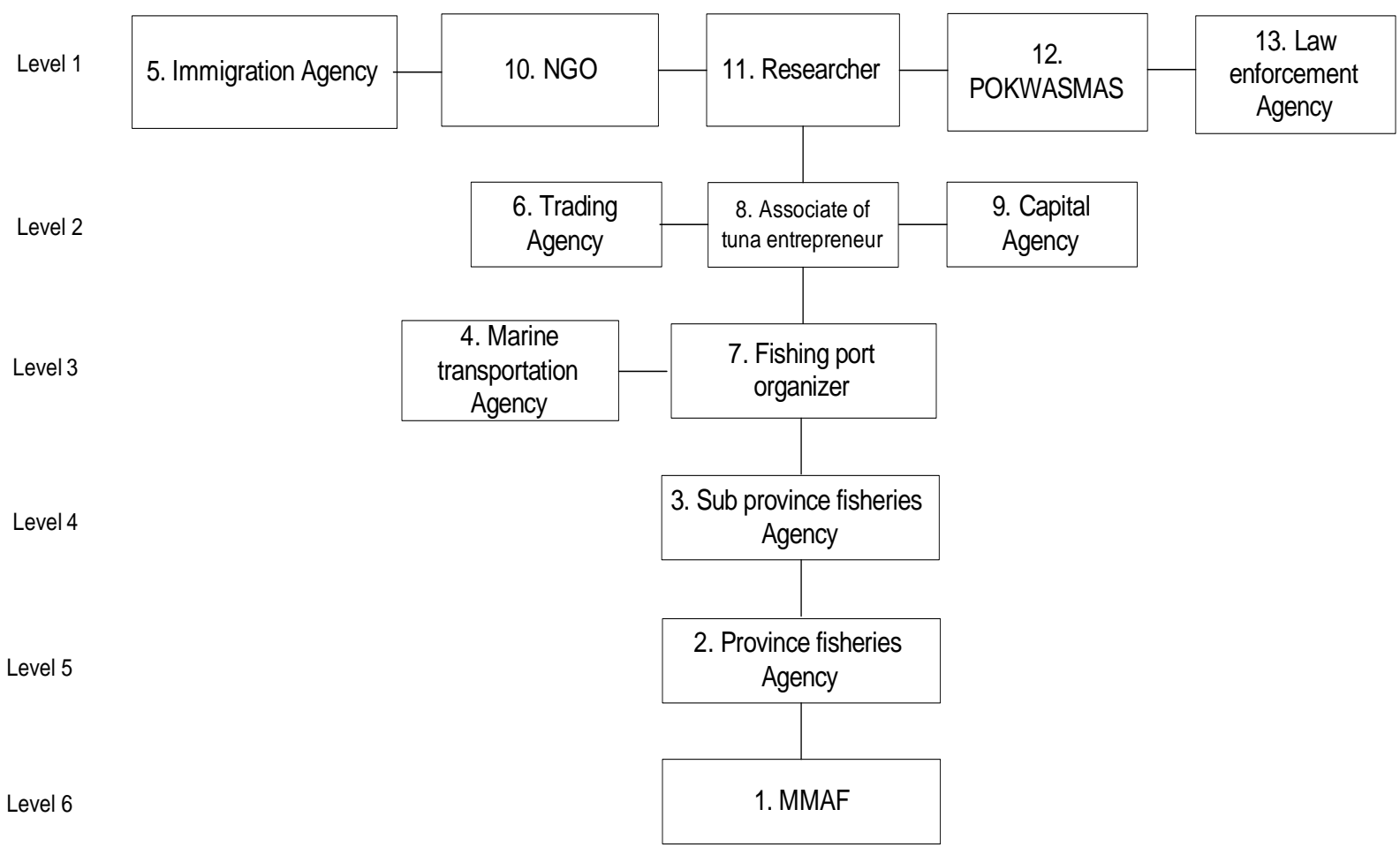

Figure 8. Structural model of institution concerned for the efficacy of program.

Fisherman group, tuna entrepreneur association, capital institution, POKWASMAS, and law enforcement institution were in sector III. The Institutes have strong relation and high drive to the efficacy of system. Ministry of Marine Affairs and Fishery and Province Fisheries Agency were in sector IV, represent that institutions have low relation with other sub system, but influence sub element from other related institution, and also have strong drive to the efficacy of system.

Development of tuna fisheries can't be conducted spatial every province or sub province, but integrated for entire South Java territorial waters. Coordination should be centrally conducted, in this case the role of Ministry of Marine Affairs and Fishery is very important. Previously, model recommended for developing tuna fisheries in South Coast o Java require integrated institution. Institution meant as resources management executor, while management authority is Ministry of Marine Affairs and Fishery. The institution is expected can accommodate the necessity between province or sub province and also between stakeholders. Institution is functioned to manage the utilization of tuna resources optimally, sustainability and in justice. Involvement of stakeholders require in planning, composing policy, conducting, monitoring, and evaluating the management of fish resources (Nurani et al., 2008). 
Key sub element lock and sub element plot which including into sector III and IV as a whole from seven element which required attention for the efficacy of development tuna fisheries program in south coast of Java presented in Table 1.

Table 1. Key element and element in sector III and IV for applying strategy of tuna fisheries development model in south coast of Java

\begin{tabular}{|c|c|c|c|c|}
\hline No. & $\begin{array}{l}\text { System } \\
\text { element }\end{array}$ & Key element & Element in sector III & $\begin{array}{l}\text { Element in } \\
\text { sector IV }\end{array}$ \\
\hline 1. & $\begin{array}{l}\text { Affected } \\
\text { society sector }\end{array}$ & $\begin{array}{lc}\text { Tuna fishery } \\
\text { entrepreneur }\end{array}$ & $\begin{array}{l}\text { Bait capture fisherman, supporting provision, } \\
\text { tuna processing industry, merchant, and } \\
\text { exporter. }\end{array}$ & $\begin{array}{l}\text { Fisherman, } \\
\text { tuna fishery } \\
\text { entrepreneur. }\end{array}$ \\
\hline 2. & $\begin{array}{l}\text { Required factor } \\
\text { for succeeding } \\
\text { program }\end{array}$ & $\begin{array}{l}\text { The availability } \\
\text { of runa } \\
\text { resources, the } \\
\text { availability of } \\
\text { data and } \\
\text { information }\end{array}$ & $\begin{array}{l}\text { The siding of central government, the siding } \\
\text { of province government, the siding of sub } \\
\text { province government, society participation, } \\
\text { role of elite figure, cooperation among area, } \\
\text { coordination among sector, the availability of } \\
\text { capital, supporting policy, supporting } \\
\text { institution, technology, data, and information, } \\
\text { law enforcement. }\end{array}$ & $\begin{array}{l}\text { The availability } \\
\text { of runa } \\
\text { resources, the } \\
\text { availability of } \\
\text { human } \\
\text { resources. }\end{array}$ \\
\hline 3. & $\begin{array}{l}\text { The main } \\
\text { constraint }\end{array}$ & $\begin{array}{l}\text { High price of } \\
\text { gasoline, low } \\
\text { priority of } \\
\text { development } \\
\text { fund, low capital } \\
\text { capability of } \\
\text { entrepreneur }\end{array}$ & $\begin{array}{l}\text { Low human resources quality, limited capture } \\
\text { technology, low understanding of fish quality, } \\
\text { limited market access, low capital capability } \\
\text { of tuna entrepreneur, limited quality and } \\
\text { quantity of fishery management, necessity } \\
\text { conflict among local government, and } \\
\text { necessity conflict among sector. }\end{array}$ & $\begin{array}{l}\text { High price of } \\
\text { gasoline, } \\
\text { limited } \\
\text { development } \\
\text { fund priority. }\end{array}$ \\
\hline 4. & $\begin{array}{l}\text { The main target } \\
\text { of program }\end{array}$ & $\begin{array}{l}\text { Optimization of } \\
\text { fish resources } \\
\text { utilization, } \\
\text { increasing } \\
\text { income and } \\
\text { fisherman } \\
\text { prosperity }\end{array}$ & $\begin{array}{l}\text { Increasing profit, increasing income and } \\
\text { fisherman prosperity, increasing the work } \\
\text { opportunity, increasing port functionality, } \\
\text { increasing port accessibility, increasing } \\
\text { income, and economic of local government. }\end{array}$ & $\begin{array}{l}\text { Optimization of } \\
\text { fish resources } \\
\text { utilization. }\end{array}$ \\
\hline 5. & $\begin{array}{l}\text { The measuring } \\
\text { rod of program } \\
\text { efficacy }\end{array}$ & $\begin{array}{l}\text { Increased } \\
\text { fishery income, } \\
\text { labor absorption }\end{array}$ & $\begin{array}{l}\text { Increasing institution role, executing } \\
\text { development program, cost efficiency of } \\
\text { program, balance benefit value among area, } \\
\text { increasing income, and economic local } \\
\text { government. }\end{array}$ & $\begin{array}{l}\text { optimization } \\
\text { the resources } \\
\text { utilization, } \\
\text { increasing } \\
\text { income and } \\
\text { labor } \\
\text { absorption. }\end{array}$ \\
\hline 6. & $\begin{array}{l}\text { Required } \\
\text { activity }\end{array}$ & $\begin{array}{l}\text { Making work } \\
\text { plan for } \\
\text { resources } \\
\text { management }\end{array}$ & $\begin{array}{l}\text { Education and human resources planning, } \\
\text { technology development, supporting } \\
\text { infrastructure, supporting condition, } \\
\text { development market access, and increasing } \\
\text { information access. }\end{array}$ & $\begin{array}{l}\text { Making work } \\
\text { plan for } \\
\text { resources } \\
\text { management. }\end{array}$ \\
\hline 7. & $\begin{array}{l}\text { Concerned } \\
\text { institution }\end{array}$ & $\begin{array}{l}\text { Ministry of } \\
\text { Marine Affairs } \\
\text { and Fishery }\end{array}$ & $\begin{array}{l}\text { Sub province fishery duty, marine } \\
\text { transportation duty, commerce duty, port } \\
\text { organizer, fisherman group, tuna } \\
\text { entrepreneur association, capital institution, } \\
\text { POKWASMAS, and law enforcement } \\
\text { institution. }\end{array}$ & $\begin{array}{l}\text { Ministry of } \\
\text { Marine Affairs } \\
\text { and Fishery, } \\
\text { province } \\
\text { fishery duty. }\end{array}$ \\
\hline
\end{tabular}

\section{CONCLUSION}

1. There are seven elements require to consider strategy in applying development model of tuna fisheries in south coast of Java, are affected society sector; required factor; main constraint; main target; indicator for efficacy; required activity; and related institution. 
2. Key sub element as factor which important role for efficacy of applying model from each element, are tuna entrepreneur, the availability of tuna resources, the availability of data and information, high price of gasoline, limited capital of entrepreneur, low development capital priority, optimization of tuna resources utilization, increasing income and labor absorption, making work plan activity, and Ministry of Marine Affairs and Fishery.

\section{ACKNOWLEDGEMENTS}

This study is regional fisheries development focusing on specific local potency in 2004-2006 funded by BPPS/DEPDIKNAS.

\section{REFERENCE}

Balanos, R., F. Emilio, N. Alfredo, \& P. Pablo. 2005. Using interpretative structural modeling in strategic decision making groups. Management Decision. 43 (19): 877-895.

Dahuri, R. 2003. Paradigma baru pembangunan Indonesia berbasis kelautan. Orasi IImiah Guru Besar. Institut Pertanian Bogor. Bogor. 233 pp.

Eriyatno. 2003. IImu Sistem, Meningkatkan Mutu, dan Efektivitas Manajemen. Institut Pertanian Bogor. Press Bogor. 147 pp.

Gorvett, R. \& N. Liu. 2007. Using Interpretative Structural Modeling to Identify and Quantify Interactive Risks. ASTIN Colloquium. Orlando. FL.

http://www. lotc.org/files/proceedings/2009/wptt/IOTC2009-WPTT-REJ.pdf.

Liu, S., X. Gao, Q. Zen, Y. Zhou, Y. Huang, W. Han, L. Li, J. Li, \& Y. Pu. 2009. Studies on interpretative structural model for forest ecosystem management decision making. complex science. First International Conference. Complex 2009. Shanghai. China. 23-25 Februari 2009.

Mandal, A. \& S. G. Deshmukh. 1994. Vendor selection using interpretative structural modeling. International Journal of Operations and Production Management. 14 (6): 52-59.

Marimin. 2004. Teknik dan Aplikasi Pengambilan Keputusan, Kriteria Majemuk. Grasindo. Jakarta. $197 \mathrm{pp}$.

Nalendra, H. 2007. Perkembangan industri perikanan Indonesia kini dan mendatang. Makalah Temu Bisnis Perikanan Tangkap: Membangun Keberlanjutan Usaha Perikanan melalui Sinergi antara Akademisi, Industri, dan Pemerintah. Bogor. Tanggal 29 Nopember 2007.

Nurani, T. W., J. Haluan, S. Sudirman, \& E. Lubis. 2008. Rekayasa sistem pengembangan perikanan tuna di perairan selatan Jawa. Forum Pascasarjana. 31 (2): 79-92.

Sagheer, S., S. Surendra, Yadav, \& S. G. Deshmukh. 2009. An application on interpretative structural modeling of the compliance to food standards. International Journal of Productivity and Performance Management. 58 (2): 136-159.

Utomo, T. P., A. M. Fauzi, T. Tedja, M. Romli, A. Aman, \& S. Honggokusumo. 2008. Kajian perbaikan agroindustri karet remah menggunakan interpretative structural modeling. Prosiding Seminar Nasional Sains dan Teknologi II. Universitas Lampung. Tanggal 17-18 Nopember 2008. 